\title{
PENGARUH SUBSTITUSI TEPUNG TERIGU DENGAN TEPUNG KENTANG HITAM (Coleus tuberosus) TERHADAP SIFAT KIMIA DAN ORGANOLEPTIKCOOKIES
}

\author{
[The Effect of Wheat Flour Substition with Coleus tuberosus Flour on Chemical and Organoleptic \\ Properties of Cookies]
}

Siska Cicilia*, Eko Basuki, Agustono Prarudiyanto, Ahmad Alamsyah, Dody Handito

Program Studi Ilmu dan Teknologi Pangan Fakultas Teknologi Pangan dan Agroindustri Universitas Mataram *email: siskacicilia@unram.ac.id

\begin{abstract}
Cookies is one type of populer biscuits. The basic ingredients of cookies are generally wheat flour. The availability of wheat flour in Indonesia is dependent on imports. To overcome this, the substitute of wheat flour is needed. Alternative materials can from tubers one of them is a black potato. The objective of this research were to substitute wheat flour with black potato starch for cookie manufacture and to analyze chemical composition and physical properties of cookies. The design used was Completely Randomized Design (CRD) with flour flour treatment: black potatoes are 100\%, 90\%: 10\%, 80\%: 20\%, 70\%: 30\%, 60\%: 40\%, and 50\%: 50\%. The addition of black potato starch cause a decrease in water content, protein content, fat content and increased ash content of cookies. The addition of potato starch up to $30 \%$ produces the preferred cookies that accepted by panelists.
\end{abstract}

Key words: Coleus tuberosus, cookies, wheat flour

\section{ABSTRAK}

Cookies (kue kering) merupakan salah satu jenis biskuit yang banyak disukai oleh masyarakat dari berbagai kalangan. Bahan dasar pembuatan cookies umumnya adalah tepung terigu. Ketersediaan tepung terigu di Indonesia masih tergantung pada impor. Untuk mengatasi hal tersebut maka diperlukan bahan alternatif pengganti terigu. Bahan alternatif bisa berasal dari umbi-umbian salah satunya adalah kentang hitam. Penelitian ini bertujuan untuk mensubstitusi tepung terigu dengan tepung kentang hitam pada pembuatan cookies serta menganalisa komposisi kimia dan sifat fisik cookies tersebut. Rancangan yang digunakan adalah Rancangan Acak Lengkap (RAL) dengan perlakuan tepung terigu tepung : kentang hitam yaitu 100\%, 90\%:10\%,80\%: 20\%, 70\%:30\%, 60\%:40\%, dan 50\%:50\%. Penelitian ini dilakukan di laboratorium pengolahan pangan dan laboratorium kimia dan biokimia pangan Fatepa Universitas Mataram. Penambahan tepung kentang hitam menyebabkan penurunan kadar air, kadar protein, kadar lemak dan peningkatan kadar abu cookies.Penambahan tepung kentang sampai 30\% menghasilkan cookies yang disukai panelis.

Kata kunci: cookies, kentang hitam, tepung terigu

\section{PENDAHULUAN}

Kue kering (cookies) merupakan salah satu jenis biskuit yang banyak disukai oleh masyarakat dari berbagai kalangan. Kue ini terbuat dari adonan lunak, teksturnya tidak begitu padat dan sangat renyah dibuat dengan proses pemanasan dan pencetakan. Bahan utama pembuatan cookiesadalah tepung, lemak, dan bahan pengembang sedangkan bahan tambahan yang merupakan bahan pelezat adalah telur, susu, gula, garam, dan lain sebagainya (Kusuma, 2008). Faktor yang mempengaruhi keberhasilan dalam membuat produk cookies adalah formula adonan yang tepat yang meliputi jenis bahan dan jumlah bahan yang digunakan. Selain itu, tahapan proses seperti pengadukan dan pemanggangan akan menentukan cookies yang dihasilkan (Hendrasty, 2013).
Tepung yang umumnya digunakan dalam pembuatan cookies adalah tepung terigu yang terbuat dari gandum. Kebutuhan terhadap terigu setiap tahun mengalami peningkatan. Impor tepung terigu Indonesia dari tahun ke tahun terus meningkat. Pada tahun 2015 impor tepung terigu sebesar 97 ribu ton (BPS, 2015), sedangkan pada tahun 2016 impor tepung terigu sebesar 148 ribu ton (BPS, 2016). Hal ini akan berdampak negatif terhadap Indonesia secara ekonomi dan sosial. Untuk mengatasi ketergantungan terhadap tepung terigu maka perlu dicari bahan alternatif pengganti terigu. Salah satu alternatif yang bisa dikembangkan adalah umbi-umbian yaitu kentang hitam.

Kentang hitam (Coleus tuberosus) merupakan salah satu umbi-umbian yang 
mengandung karbohidrat yang tinggi. Kentang hitam memiliki karbohidrat sebesar 33,7 g/100 g; lebih tinggi daripada kentang dan ubi jalar yang memiliki karbohidrat sebesar $13,5 \mathrm{~g} / 100$ $\mathrm{g}$ dan 20,6 g/100 g (Persatuan Ahli Gizi Indonesia, 2009). Selain itu, kentang hitam mengandung vitamin $\mathrm{C}$ dan mineral yang cukup tinggi. Mineral yang terdapat di kentang hitam antara lain kalsium, fosfor, dan besi. Kentang hitam selain dimanfaatkan sebagai bahan pangan dapat juga dimanfaatkan dalam pengobatan, seperti kanker. Menurut Nugraheni dkk (2012), ekstrak kulit dan daging kentang hitam menggunakan etanol dapat digunakan sebagai antioksidan dan anti poliferasi alami.

Belum banyak penelitian terkait dengan penggunaan kentang hitam dalam pembuatan produk cookies. Beberapa penelitian yang sudahdilakukan adalah dalam pembuatan roti tawar menggunakan tepung kentang hitam dan tepung terigu (10\%:90\%) menghasilkan roti terbaik dari kandungan gizi serta dapat diterima oleh panelis (Rahman, 2010). Substitusi tepung terigu dengan resistant starch kentang hitam sampai $20 \%$ pada pembuatan crackers menghasilkan crackers terbaik dari segi gizi (Nugraheni dkk, 2015). Pemanfaatan kentang hitam dalam pembuatan cookies merupakan upaya diversifikasi produk pangan dan upaya meningkatkan nilai ekonomi umbi tersebut.Penelitian ini bertujuan untuk mensubstitusi tepung terigu dengan tepung kentang hitam pada pembuatan cookies serta menganalisa komposisi kimia dan sifat fisik cookies tersebut.

\section{METODOLOGI}

\section{Bahan dan Alat}

Bahan utama yang digunakan adalah tepung terigu, kentang hitam, gula, telur, air, garam, susu, aquades, dan mentega. Peralatan yang digunkan adalah glassware, timbangan analitik, kompor gas, timbangan kasar, mixer, oven, cetakan, mangkok, loyang, nyiru, pisau stainless steel, destilator, ayakan 100 mesh, eksikator, labu ukur, pipet, tampah, wajan stainless steel, ember plastik, karung plastik, mangkok plastik, kuas besar dan kecil, cetakan kue,lap, piring, panelis, quisioner,dan alat tulis menulis

\section{Metode}

Metode yang digunakan pada penelitian ini adalah metode eksprimental yang terdiri dari 6 aras dan diulang sebanyak 3 kali yaitu sebagai berikut:

$1=$ Tepung terigu $100 \%$

$2=$ Tepung terigu $90 \%$ : tepung kentang hitam $10 \%$

$3=$ Tepung terigu $80 \%$ : tepung kentang hitam $20 \%$

$4=$ Tepung terigu $70 \%$ : tepung kentang hitam $30 \%$

$5=$ Tepung terigu $60 \%$ : tepung kentang hitam $40 \%$

$6=$ Tepung terigu $50 \%$ : tepung kentang hitam $50 \%$

Apabila ada perbedaan nyata antara perlakuan maka dilakukan uji lanjut dengan menggunakan beda nyata terkecil (BNT) pada taraf nyata yang sama (Hanafiah, 2002).

\section{Pembuatan Cookies Kentang Hitam}

\section{Pencampuran I dan Pencampuran II}

Semua bahan dari kelompok I dicampur dalam wadah dan dilakukan pencampuran menggunakan mixer hingga diperoleh adonan yang licin.Bahan kelompok II berupa kuning telur ditambahkan satu per satu ke bahan kelompok I, kemudian dimixer hingga diperoleh adonan yang homogen.

\section{Pencampuran III dan Pengulenan.}

Bahankelompok III ditambahkan, kemudian diaduk hingga diperoleh adonan yang kering, licin dan elastis. Lama pengulenan untuk setiap adonan 4 menit.

\section{Penggilingan.}

Adonan kemudian digiling menjadi lembaran (tebal $\pm 0,3 \mathrm{~cm}$ ) menggunakan penggiling kue yang berasal dari kayu.

\section{Pencetakan.}

Pencetakan dilakukan dengan menggunakan bantuan alat berupa cetakan dari alumunium.

\section{Pengolesan dengan Kuning Telur.}

Cookies yang sudah dicetak ditempatkan pada loyang dan dioles dengan kuning telur. Hal ini bertujuan untuk memberi warna atau kenampakan yang lebih bagus pada biskuit.

\section{Pemanggangan.}

Suhu pemanggangan pada cookies $170^{\circ} \mathrm{C}$ selama 30 menit. Pemanggangan dilakukan menggunakan oven listrik. Proses pembuatan cookies kentang hitam dapat dilihat pada Gambar 1. 
Versi Online:

http://www.profood.unram.ac.id/index.php/profood

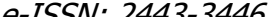

Persiapan bahan

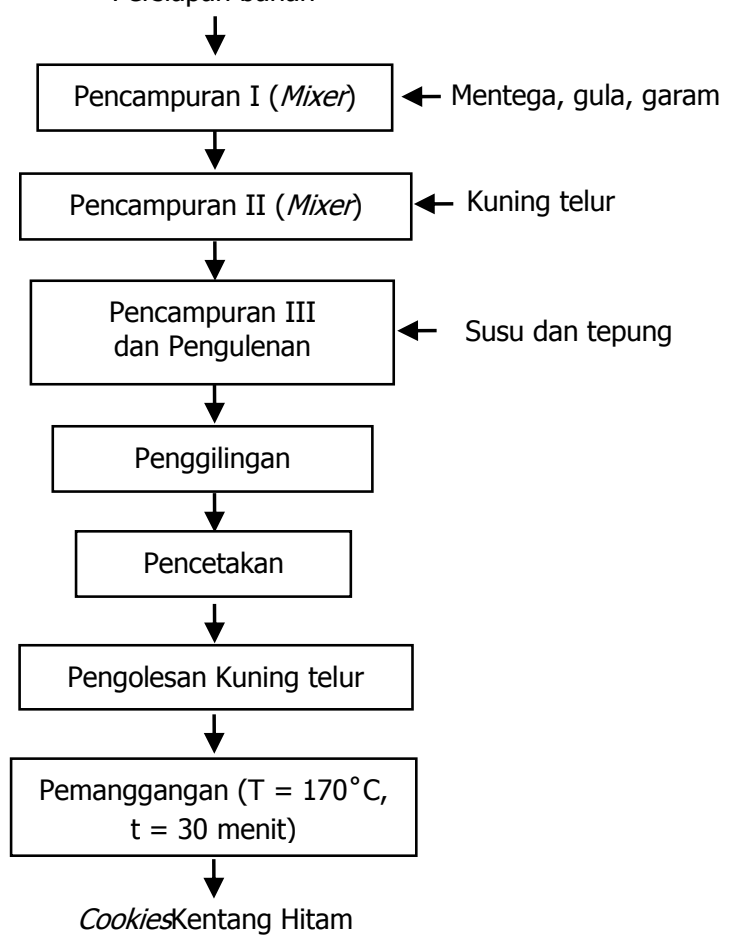

Gambar 1. Diagram Alir Pembuatan Cookies Kentang Hitam

Parameter kimia meliputi, kadar air (metode termogravimetri), kadar abu (pengabuan kering), kadar lemak (metode soxhlet), dan kadar protein. Parameter organoleptik berupa rasa (hedonic), tekstur (hedonic), dan warna (scoring)

\section{HASIL DAN PEMBAHASAN}

Hasil pengamatan dan analisa keragaman berikut uji lanjut untuk setiap parameter yang diamati dapat dilihat pada lampiran, sedangkan analisa keragaman parameter beserta uji lanjut dapat dilihat pada Tabel1 dan Tabel 2.

Tabel 1. Signifikansi Analisa Keragaman Beberapa Parameter Kimia Cookies dari Tepung Terigu dan Tepung Kentang Hitam

\begin{tabular}{lc}
\hline \multicolumn{1}{c}{ Parameter } & \multicolumn{1}{c}{ Hasil } \\
\hline \multicolumn{1}{c}{ Cookies } \\
Kadar Air (\%) & $2135,8 \mathrm{~S}$ \\
Kadar Abu (\%) & $484,1 \mathrm{~S}$ \\
Kadar Protein (\%) & $861,2 \mathrm{~S}$ \\
Kadar Lemak (\%) & $15,9 \mathrm{~S}$ \\
\hline F tabel = 3,11 \\
\hline Keterangan ; S = Signifikan (berbeda nyata) \\
\multicolumn{2}{c}{ NS = Non Signifikan (tidak } \\
\multicolumn{2}{c}{ berbeda nyata) }
\end{tabular}

Pro Food (Jurnal Ilmu dan Teknologi Pangan)

Vol 4 No. 1 Mei 2018

ISSN: 2443-1095

Tabel 2. Signifikansi Analisa Keragaman Beberapa Parameter Organoleptik Cookies dari Tepung Terigu dan Tepung Kentang Hitam

\begin{tabular}{|c|c|}
\hline Parameter & Hasil \\
\hline \multicolumn{2}{|c|}{ Cookies Kentang Hitam } \\
\hline Warna (Scoring) & $46,9 \mathrm{~S}$ \\
\hline Tekstur (Hedonic) & $6,6 \mathrm{~S}$ \\
\hline Rasa (Hedonic) & $12,5 \mathrm{~S}$ \\
\hline $\mathrm{F}$ tabel $=2,19$ & \\
\hline 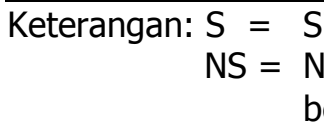 & $\begin{array}{l}\text { erbeda nyata) } \\
\text { an (tidak } \\
\text { ta) }\end{array}$ \\
\hline
\end{tabular}

\section{a. Kadar Air}

Air merupakan komponen penting dalam bahan pangan karena air dapat mempengaruhi penampakan, tekstur, serta cita rasa bahan pangan. Kadar air merupakan banyaknya air yang terkandung dalam bahan yang dinyatakan dalam persen. Tingginya kadar dalam bahan pangan menyebabkan pertumbuhan mikroorganisme lebih cepat sehingga kerusakan bahan pangan juga menjadi lebih cepat (Winarno, 2004).

Berdasarkan analisa keragaman, penambahan tepung terigu dan tepung kentang hitam memberikan pengaruh yang berbeda nyata terhadap kadar air cookieskentang hitam. Tingkat perbedaan kadar air akibat pengaruh penambahan tepung terigu dan tepung kentang hitam dapat dilihat pada Gambar 2.

Pada Gambar 2 dapat dilihat semakin tinggi penambahan tepung kentang hitam maka menyebabkan kadar air cookies cenderung menurun dimana penambahan $50 \%$ tepung kentang hitam menghasilkan kadar air terendah yaitu $2,4 \%$.

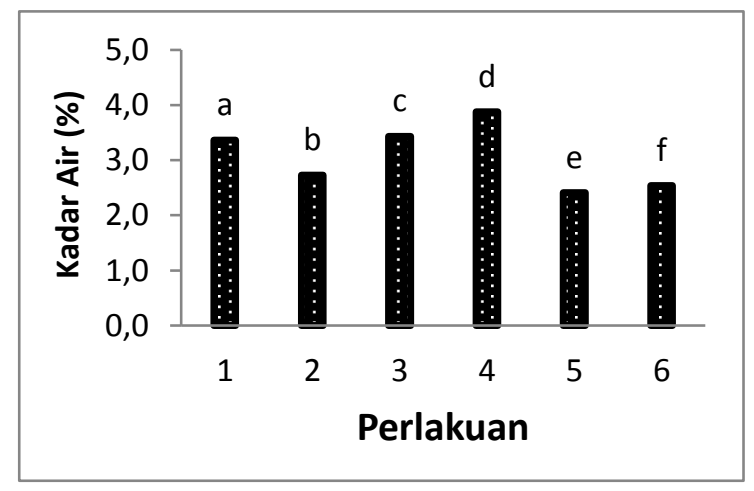

Gambar 2. Pengaruh Penambahan Tepung Terigu dan Tepung Kentang Hitam terhadap Kadar Air Cookies 


\section{b. Kadar Abu}

Kadar abu adalah zat anorganik sisa hasil pembakaran suatu bahan organik. Penentuan kadar abu berhubungan erat dengan kandungan mineral yang terdapat dalam suatu bahan, kemurnian serta kebersihan suatu bahan yang dihasilkan. Bahan makanan dibakar dalam suhu yang tinggi dan menjadi abu. Pengukuran kadar abu bertujuan untuk mengetahui besarnya kandungan mineral yang terdapat dalam makanan/pangan (Sandjaja, 2009).

Berdasarkan analisa keragaman, penambahan tepung terigu dan tepung kentang hitam memberikan pengaruh yang berbeda nyata terhadap kadar abu cookies kentang hitam. Tingkat perbedaan kadar abu akibat pengaruh penambahan tepung terigu dan tepung kentang hitam dapat dilihat pada Gambar 3.Penambahan tepung kentang hitam menyebabkan kadar abu meningkat dimana kadar abu tertinggi pada penambahan $50 \%$ tepung kentang hitam yaitu $1,8 \%$.

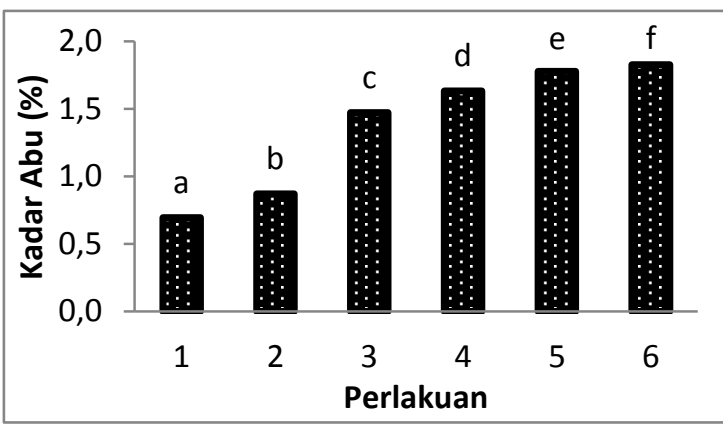

Gambar 3. Pengaruh Penambahan Tepung Terigu dan Tepung Kentang Hitam terhadap Kadar Abu Cookies

\section{c. Kadar Protein}

Fungsi protein dalam pangan antara lain fungsi Water Holding Capacity (WHC), sifat koagulasi dalam keju dan tahu, sifat stabilisasi dalam es krim, sebagai kandungan untuk beberapa pangan dan sifat emulsifikasi. Pada umumnya kadar protein di dalam bahan pangan menentukan mutu bahan pangan itu sendiri.

Berdasarkan analisa keragaman, penambahan tepung terigu dan tepung kentang hitam memberikan pengaruh yang berbeda nyata terhadap kadar protein cookies kentang hitam. Tingkat perbedaan kadar protein akibat pengaruh penambahan tepung terigu dan tepung kentang hitam dapat dilihat pada Gambar 4.

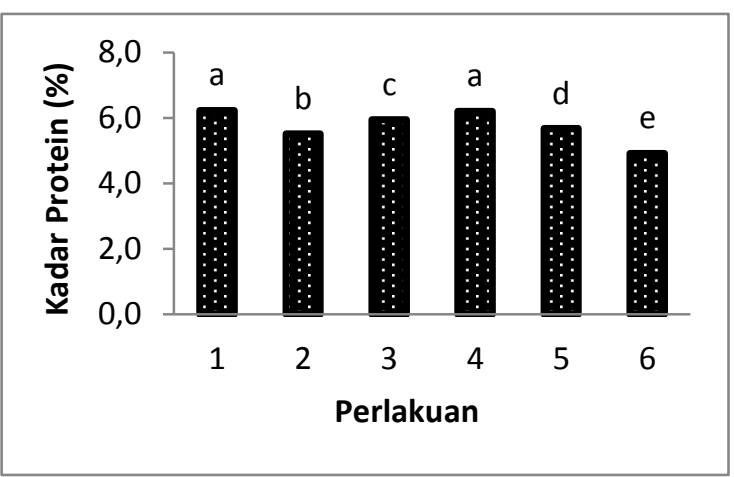

Gambar 4. Pengaruh Penambahan Tepung Terigu dan Tepung Kentang Hitam terhadap Kadar Protein Cookies

Penambahan tepung kentang hitam cenderung mengakibatkan penurunan kadar protein. Kadar protein terendah pada cookies adalah 4,9\% dengan penambahan tepung kentang hitam sebanyak 50\%.

\section{d. Kadar Lemak}

Berdasarkan analisa keragaman pada Tabel 1, penambahan tepung terigu dan tepung kentang hitam memberikan pengaruh yang berbeda nyata terhadap kadar lemak cookies kentang hitam. Tingkat perbedaan kadar lemak akibat pengaruh penambahan tepung terigu dan tepung kentang hitam dapat dilihat pada Gambar 5.

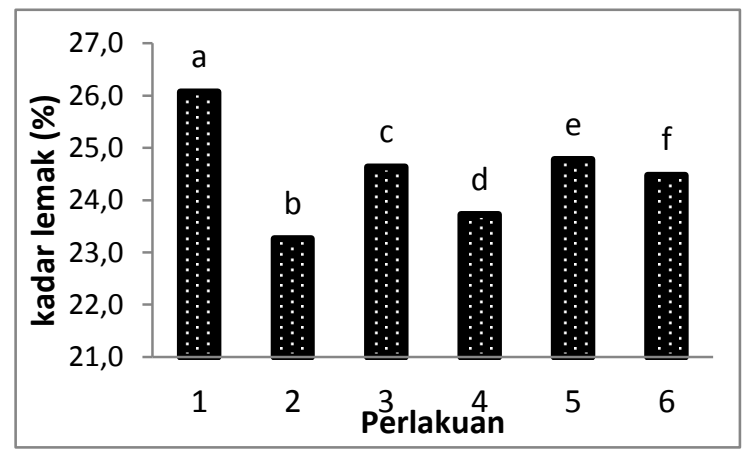

Gambar 5. Pengaruh Penambahan Tepung Terigu dan Tepung Kentang Hitam terhadap Kadar Lemak Cookies

Gambar 5. menunjukkan semakin banyak penambahan tepung terigu dan tepung kentang hitam menyebabkan kadar lemak cookies pada mengalami penurunan sampai $23,3 \%$.

\section{e. Tekstur (Hedonic)}

Tekstur merupakan segi penting dari mutu makanan, kadang-kadang lebih penting daripada bau rasa dan warna. Tekstur 
makanan dapat dievaluasi dengan uji mekanika (metode instrumen) atau dengan analisis secara pengindraan.Tekstur paling penting pada makanan lunak dan makanan renyah. Ciri yang paling sering diacu adalah kekerasan, kerenyahan, dan kandungan air (Deman, 1997).

Berdasarkan analisa keragaman, penambahan tepung terigu dan tepung kentang hitam memberikan pengaruh yang berbeda nyata terhadap tekstur cookies kentang hitam. Tingkat kesukaan tekstur akibat pengaruh penambahan tepung terigu dan tepung kentang hitam dapat dilihat pada Gambar 6.

Semakin banyak penambahan tepung kentang hitam menyebabkan nilai tekstur menurun pada cookies. Tingkat kesukaan terendah dari ketiga jenis produk bakery ditemukan pada donat dengan penambahan $50 \%$ tepung kentang hitam. Hal ini disebabkan oleh donat dengan bahan dasar non terigu akan menghasilkan cookies yang bertekstur keras dan tidak renyah.Tekstur yang dihasilkan masih disukai oleh panelis berdasarkan uji organoleptik.

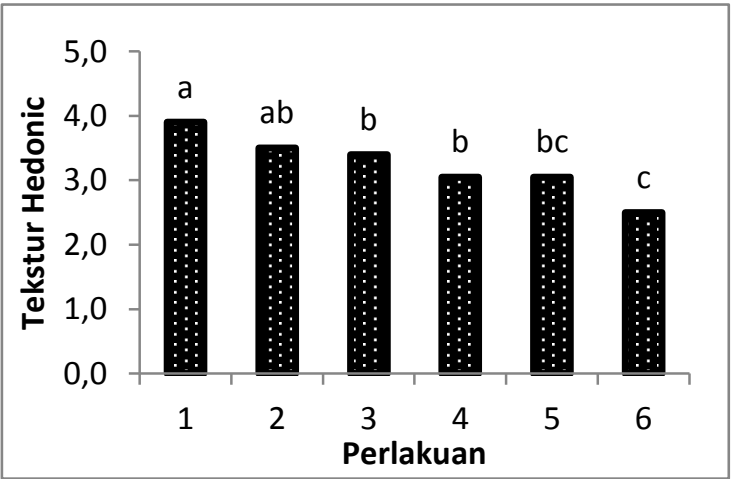

Gambar 6. Pengaruh Penambahan Tepung Terigu dan Tepung Kentang Hitam terhadap Tekstur (Hedonic) Cookies

\section{f. Rasa (Hedonic)}

Preferensi terhadap makanan didefinisikan sebagai derajat kesukaan atau ketidaksukaan terhadap makanan dan preferensi ini akan berpengaruh terhadap konsumsi pangan. Salah satu faktor penentu preferensi makanan adalah rasa dari makanan tersebut. Meskipun parameter lain nilainya baik, jika rasa tidak enak atau tidak disukai maka produk akan ditolak (Soekarto, 1985). Menurut Winarno (2004), rasa suatu bahan pangan dipengaruhi oleh beberapa faktor yaitu senyawa kimia, temperatur, dan interaksi dengan komponen rasa yang lain.

Berdasarkan analisa keragaman, penambahan tepung terigu dan tepung kentang hitam memberikan pengaruh yang berbeda nyata terhadap rasa (hedonic) cookies kentang hitam. Tingkat kesukaan rasa akibat pengaruh penambahan tepung terigu dan tepung kentang hitam dapat dilihat pada Gambar 7.

Semakin banyak tepung kentang hitam yang digunakan pada pembuatan cookies mengakibatkan rasa produk cenderung tidak disukai. Penambahan 50\% tepung kentang hitam menghasilkan cookiesyang memiliki tingkat kesukaan rasa terendah. Hal ini disebabkan panelis belum terbiasa mengkonsumsi cookiesyang terbuat dari substitusi tepung terigu dalam jumlah relatif besar. Kesukaan sangat dipengaruhi oleh subyektivitas konsumen (panelis), sehingga akan mempengaruhi suatu produk dapat diterima oleh konsumen atau tidak.

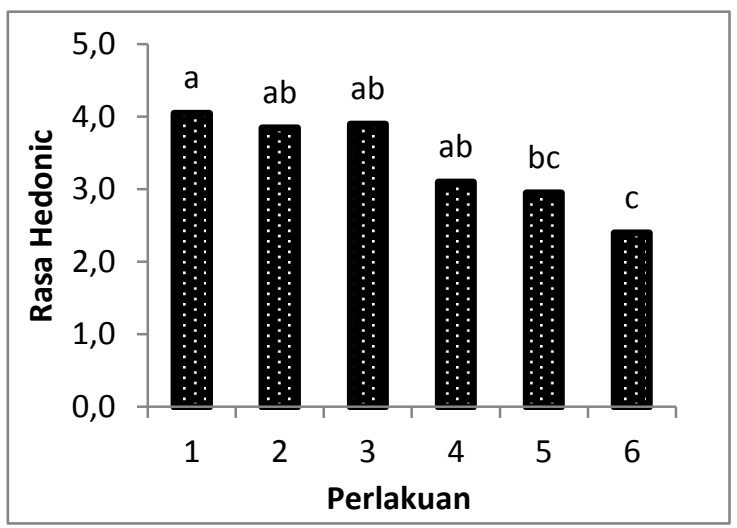

Gambar 7. Pengaruh Penambahan Tepung Terigu dan Tepung Kentang Hitam terhadap Rasa (Hedonic) Cookies

\section{g. Warna}

Warna merupakan komponen yang sangat penting dalam menentukan kualitas dan derajat penerimaan dari suatu bahan pangan. Selain itu, warna dapat memberi petunjuk mengenai perubahan kimia dalam makanan (de Man, 1997). Warna juga merupakan salah satu parameter yang digunakan konsumen dalam memilih produk.

Pengujian warna cookies menggunakan metode scoring test dan colourimeter. Berdasarkan analisa keragaman,penambahan tepung terigu dan tepung kentang hitam memberikan pengaruh yang berbeda nyata terhadap warna cookies. Tingkat perbedaan warna akibat pengaruh penambahan tepung 
terigu dan tepung kentang hitam dapat dilihat pada Gambar 8 dan 9.

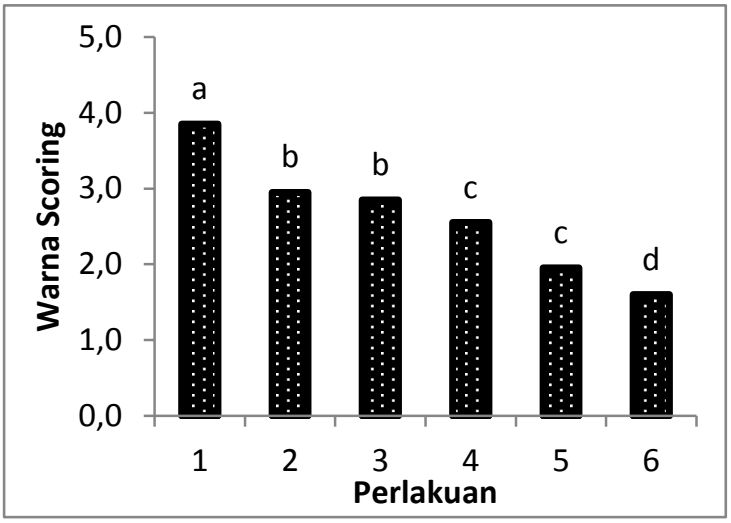

Gambar 8. Pengaruh Penambahan Tepung Terigu dan Tepung Kentang Hitam terhadap Warna (Scoring) cookies

Berdasarkan Gambar 8 semakin banyak tepung kentang hitam yang digunakan pada pembuatan produk bakery mengakibatkan warna pada ketiga jenis produk semakin gelap. Hal ini disebabkan oleh warna tepung kentang hitam memiliki warna lebih gelap daripada tepung terigu. Warna cokelat pada cookies disebabkan oleh proses pemanggangan dan penggorengan adonan yang merupakan reaksi Maillard. Adapun nilai warna menggunakan colourimeter dapat dilihat pada Gambar 9.

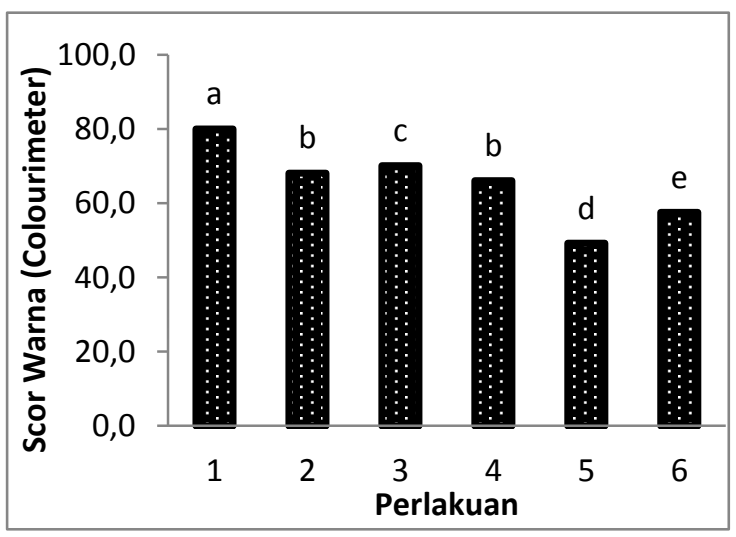

Gambar 9. Pengaruh Penambahan Tepung Terigu dan Tepung Kentang Hitam terhadap Warna (Colourimeter) Cookies

Penambahan tepung terigu dan tepung kentang hitam mengakibatkan nilai $\mathbf{L}$ cenderung mengalami penurunan yang menunjukkan warna pada cookies semakin gelap (cokelat). Warna cokelat disebabkan oleh proses pemanggangan adonan yang merupakan reaksi Maillard. Reaksi Maillard terjadi bila gula pereduksi bereaksi dengan senyawa-senyawa yang memiliki gugus $\mathrm{NH}_{2}$ (protein, asam amino, dan peptida). Reaksi ini terjadi bila bahan pangan dipanaskan. Ketika gula pereduksi bereaksi dengan sebuah gugus amina primer/skunder akan membentuk suatu glukosamin. Komponen-komponen ini selanjutnya membentuk komponen berwarna gelap melanoidin yang menyebabkan perubahan warna pada bahan pangan (Winarno, 2004).

\section{KESIMPULAN}

Berdasarkan hasil analisa dan pembahasan maka dapat disimpulkan bahwa:

1. Penambahan tepung kentang hitam menyebabkan penurunan kadar air, kadar protein, kadar lemak dan peningkatan kadar abucookies.

2. Penambahan tepung kentang sampai $30 \%$ menghasilkan cookies yang disukai panelis.

3. Semakin banyak tepung kentang hitam yang ditambahkan menghasilkan cookies dengan warna semakin gelap.

\section{DAFTAR PUSTAKA}

deMan, JM, 1997. Kimia Makanan. Institut Teknologi Bandung, Bandung.

Departemen Perindustrian dan Perdagangan RI. 1993. Standar Nasional Industri untuk Biskuit. Direktorat Jendral Industri Kecil RI, Jakarta.

Faridah A, Pada KS, Yulastri A, dan Yusuf L. 2008. Patiseri Jilid 1. Direktorat Jenderal Manajemen Pendidikan Dasar dan Menengah, Departemen Pendidikan Nasional, Jakarta.

Hendrasty HK. 2013. Bahan Produk Bakery. Graha Ilmu, Jogjakarta

IkrawanY. 2006. Biskuit Makanan Pengganti Saat Lapar. http://www.pikiranrakyat.com. [ 9 April 2017]

Kramer A and Twigg BS. 1966. Fundamental of Quality Control the Food Industry. The AVI Publishing Company Inc. Westport Connecticut.

Matz \& Matz TD. 1998. Cooke \& Cracer Technology. AVI.co.Inc, Westport. Connecticut. 
Versi Online:

http://www.profood.unram.ac.id/index.php/profood e-ISSN: 2443-3446

Miftakhussolikhah, Ariani D, Angwar M, Kevin J. 2017. Cooking Characterization of Coleus tuberosus Noodle in Various Arenga Starch Substitution. AIP Conference Proceedings.

Nkansah GO. 2004. Solenostemon rotundifolius (Poir.) J. K. Morton. PROTA 2 : Vegetables! Legumes. Wageningen, Netherlands

Nugraheni M, Hamidah S, dan Aulina R. 2015. Resistant Starch Tipe 3 Tepung Kentang Hitam (Coleus tuberosus) sebagai Makanan Fungsional untuk Manajemen Penyakit Degeneratif. Universitas Negeri Jogjakarta, Jogjakarta.

Persatuan Ahli Gizi Indonesia. 2009. Tabel Komposisi Pangan Indonesia. PT Elex Media Komputindo, Jakarta.
Pro Food (Jurnal IImu dan Teknologi Pangan)

Vol 4 No. 1 Mei 2018 ISSN: 2443-1095

Sandjaja. 2009. Kamus Gizi Pelengkap Kesehatan Keluarga. PT Kompas Medida Nusantara, Jakarta.

SNI 01-2973-1992. Biskuit. Badan Standar Nasional (BSN). Jakarta.

SNI 01-3840-1995. Roti Tawar. Badan Standar Nasional (BSN). Jakarta.

Soekarto ST. 1997. Tekno Pangan dan Agroindustri. Jurusan Teknologi Pangan dan Gizi. Fakultas Teknologi Pertanian, Bogor.

Soewarno $\mathrm{T}$ dan Sukanto. 1985. Dasar Penelitian Organoleptik Untuk Perindustrian Pangan dan Hasil Pertanian. Bathara Aksara, Jakarta

Winarno FG. 2004. Kimia Pangan dan Gizi. PT Gramedia Pustaka Utama, Jakarta. 